\title{
THE CORRELATION BETWEEN ISOKINETIC STRENGTH OF KNEE EXTENSORS AND VERTICAL JUMP PERFORMANCE IN ADOLESCENT SOCCER PLAYERS IN AN ANNUAL TRAINING CYCLE
}

\author{
Michal Lehnert*, Zdeněk Svoboda, Roman Cuberek
}

Faculty of Physical Culture, Palacký University, Olomouc, Czech Republic

Submitted in January, 2013

BACKGROUND: Isokinetic testing is often used to provide coaches with important information about the physical status of athletes. Therefore, a number of studies is focused on the assessment of the relationship between isokinetic and functional tests. The results of a limited number of studies indicate that the relationship changes in different training periods.

OBJECTIVE: The aim of the study was to determine the relationship between the characteristics of the isokinetic strength of knee extensors and vertical jump performance in three different periods of the annual training cycle in adolescent soccer players.

METHODS: A group of adolescent soccer players ( $N=16$; average age $16.7 \pm 0.7$ years) was tested at the end of the competitive season, at the beginning of the off-season and during the sixth week of a new competitive season. The isokinetic concentric peak torque (PT), peak power (Pmax) and time to peak torque (TPT) of the dominant leg and non-dominant leg were measured at angular velocities of $60^{\circ} \cdot \mathrm{s}^{-1}, 180^{\circ} \cdot \mathrm{s}^{-1}, 360^{\circ} \cdot \mathrm{s}^{-1}$. The explosive strength of the lower extremities was measured using the countermovement jump with free arms (CMJF) method and countermovement jump with the arms crossed over the chest (CMJ). Based on literary reviews, a logically significant value of the correlation was set at $>.30$.

RESULTS: The correlations between the isokinetic strength characteristics and vertical jump performance irrespective of the training period were low to moderate; $56 \%$ of the correlations were $>.30$. In the different periods of the annual training cycle, the occurrence of correlations $>.30$ as well as their value varied $-67 \%$ at the end of the competitive season, $31 \%$ at the beginning of the off-season and $64 \%$ at the beginning of the competitive season. For both types of jumps, the correlations for Pmax and PT parameters were the lowest during the second measurement in most cases; no trend was observed for the TPT parameter. For CMJF the highest correlation values were observed during the third measurement for the Pmax parameter in the dominant leg at $180^{\circ} \cdot \mathrm{s}^{-1}$ and $360^{\circ} \cdot \mathrm{s}^{-1}$; for CMJ during the first measurement for the Pmax and PT parameters at $180^{\circ} \cdot \mathrm{s}^{-1}$ in the dominant leg.

CONCLUSIONS: The results of the study indicate that the significance of the information obtained by measuring the strength of isokinetic extension of the knee joint to assess the jumping ability in soccer players can change during the annual training cycle and that, from this perspective, measurement at $180^{\circ} \cdot \mathrm{s}^{-1}$ and at higher velocities should be preferred.

Keywords: Periodization, sport training, testing, youth.

\section{INTRODUCTION}

An excellent level of soccer-specific fitness is one of the basic requirements that elite players must meet. In players, the decisive role is represented by their reaction speed, running acceleration, repeated sprint ability, explosive strength of lower extremities dur-

\footnotetext{
* Address for correspondence: Michal Lehnert, Department of Sport, Faculty of Physical Culture, Palacký University, tř. Míru 115, 77111 Olomouc, Czech Republic. E-mail: michal.lehnert@upol.cz
}

ing kicking, tackling, and jumping (Bradley, Wooster, Olsen, Boanas, \& Krustrup, 2009; Verheijen, 1998; Bravo, Impellizzery, Rampinini, Castagna, Bishop, \& Wisloff, 2008). These movements, including jumping, are associated with the production of dynamic force during knee extension and flexion (Cerrah, Gungor, Soylu, Ertan, Lees, \& Bayrak, 2011; Cometti-Maffiuletti, Pousson, Chatard, \& Maffuli, 2001; Luhtanen \& Komi, 1978). This fact is also confirmed by significant correlations between the maximum strength of knee extensors and flexors and explosive strength during soccer-specific movements (Newman, 2004; Stølen, 
Chamari, Castagna, \& Wisloff, 2005; Wisloff, Castagna, Helgerud, Jones, \& Hoff, 2004).

An efficient training process leading to the achievement of specific adaptation changes in the organism of players requires a systematic assessment of physical fitness. Such an assessment provides coaches with important information about the players' current physical status and becomes crucial especially in the key phases of the annual training cycle (Stone, Me. \& Stone, Mi. 2006). For the purposes of evaluation of the dynamic muscle strength in the lower extremities, various jumping and half-squat tests are primarily used (Stølen et al., 2005; Hoff, 2004; Hoff \& Helgerud, 2004). However, isokinetic dynamometry is often applied. The reason is that it is considered an objective and reliable diagnostic tool which enables the identification of torque values through a constant speed and a given range of movements and at varying limb velocities (Baltzopoulos \& Brodie, 1989; Dirnberger, Kösters, \& Müller, 2012) and is regarded as a representative method for determining muscle strength in the lower extremities in soccer players (Cerrah et al., 2011). Wrigley (2000) suggested that isokinetic testing of knee flexors and extensors is reliable and sensitive enough to explore seasonal changes in soccer players' strength.

A number of studies dealt with determining the correlation between isokinetic tests which are considered non-specific and functional tests (Morrow, 2005). These studies indicated correlations between the isokinetic strength of extensors and flexors of the knee joint and kicking power (Anthrakidis, Skoufas, Lazaridis, \& Zaggelidis, 2008), speed of the kicked ball (Cerrah et al., 2011), short distance sprints (Bračič, Hadžič, Čoh, \& Derviševič, 2011; Cotte \& Chatard, 2011; Ekblom, 2003; Newman, 2004) and various types of jumps in male soccer players (DeStaso, Kaminski, \& Perrin, 1997; Iossifidou, Baltzopoulos, \& Giakas, 2005; Özcakar, Kunduracyoğlu, Cetin, Ülkar, Guner, \& Hascelik, 2003; Tsiokanos, Kellis, E., Jamurtas, \& Kellis, S., 2002) and female soccer players (Östenberg, Roos, E., Ekdahl, \& Roos, H., 1998). The results of the studies differ; low to moderate correlations with respect to jumping ability were mostly observed.

Nevertheless, the studies mentioned above focused on a single determination of the correlation between the isokinetic strength of knee extensors and flexors and functional tests. Moreover, in most studies the correlation was expressed only by means of absolute peak torque (PT) or its relative value. There is an insufficient number of studies monitoring these correlations in soccer players in the different training periods of the annual training cycle (ATC). Malliou, Ispirlidis, Beneka, Taxildaris, and Godolias (2003) observed a changing pattern in the correlations in adult professional soccer players throughout the annual training cycle. With re- spect to the differences in the content of training sessions throughout the ATC (Gamble, 2010; Schmid \& Alejo, 2002; Stølen et al., 2005; Wirth \& Schmidtbleicher, 2007) and regarding the differences in the degree of specificity of the isokinetic test of concentric knee flexion and extension and the countermovement jump test, we assume that the value of the correlations and the number of significant correlations will also change in elite adolescent soccer players in the different periods. The aim of the study is to determine the relationship between the characteristics of isokinetic strength of the extensors of the knee joint of the dominant and non-dominant leg and vertical jump performance in elite adolescent soccer players in three different periods of the ATC.

\section{METHODOLOGY}

\section{Subjects}

The study involved a group of 16 highly trained soccer players of all playing positions (age $16.7 \pm 0.7$ years), who participated in training process five days per week and who played in the Czech U17 first league (Table 1). Leg dominance was determined according to the preferred leg for ball kicking. Prior to the study, the players, as well as their parents, were fully informed about the goal and methods of the measurements and they provided their written consent. The study was approved by the Ethical Committee of the Faculty of Physical Culture, Palacký University, Olomouc and conformed to the Declaration of Helsinki regarding the use of human subjects. On the day before testing, the players were not exposed to any high training load that could have affected the test results. Players with acute medical problems and with a history of knee related injury were excluded from the research.

\section{Data collection}

Prior to testing, the players completed non-specific warm-up exercises which included cycling on a stationary bicycle ergometer for six minutes at a self-regulated

Table 1

Somatic characteristics for the group of players $(N=16)$

\begin{tabular}{lrrcc}
\hline Variable & $M \pm S D$ & $M d n$ & Minimum & Maximum \\
\hline Height & $177.6 \pm 6.0$ & 177.5 & 166.0 & 188.0 \\
Weight_1 & $66.5 \pm 9.1$ & 65.5 & 46.6 & 85.2 \\
Weight_2 & $64.7 \pm 8.3$ & 63.4 & 46.3 & 82.2 \\
Weight_3 & $65.1 \pm 8.3$ & 64.5 & 47.3 & 82.2 \\
\hline
\end{tabular}

Note. $M d n=$ median. Height $=$ body height $(\mathrm{cm})$, Weight_1 = body weight in the first measurement, Weight_2 = body weight in the second measurement, Weight_3 = body weight in the third measurement. 
low to moderate intensity and five minutes of stretching exercises which targeted the main muscle groups involved during testing. The warm-up routine was performed under the supervision of the researcher.

The unilateral strength of the concentric action of the knee extensors was measured using an isokinetic dynamometer ISOMED 2000 (D. \& R. Ferstl GmbH, Hemau, Germany). The players were tested in the seated position and held handgrips alongside the seat with the seat back reclined by $15^{\circ}$. For the fixation of the pelvis and thigh of the tested leg, fixed straps were used; shoulders were fixed by shoulder pads in the ventral-dorsal and cranial-caudal direction. The axis of rotation of the dynamometer was aligned with the axis of the rotation of the knee (lateral femoral epicondyle). The arm of the dynamometer lever was fixed to the distal part of the shin and the lower edge of the shin pad was placed $2.5 \mathrm{~cm}$ over the medial apex malleolus. Individual seat settings were stored in PC memory before the right leg was measured and were automatically activated in the process of measuring the left leg and follow-up testing. At the beginning of follow-up testing, individual settings were rechecked and adjusted as required.

Angular velocities of $60^{\circ} \cdot \mathrm{s}^{-1}, 180^{\circ} \cdot \mathrm{s}^{-1}$ and $360^{\circ} \cdot \mathrm{s}^{-1}$ were used for the measurement in the order from the lowest to the highest velocity. A static gravitational correction was applied as well. The range of motion was set to $10-90^{\circ}$ of knee flexion $\left(0^{\circ}=\right.$ full extension $)$. The testing protocol consisted of two sets for each velocity. In the first warm-up set, the players performed five concentric/concentric reciprocal actions (with the flexion movements performed first) with a progressive rise in the muscle action until a maximum action was performed. After a 30 second rest, the players performed a set of six maximum repetitions. The rest time during the measurements at different velocities was one minute and the rest time between the measurement of the dominant leg and non-dominant leg was three minutes.

During the testing procedure, the players were provided with concurrent visual feedback in the form of an isokinetic strength curve displayed on the dynamometer monitor. Regarding the fact that the players' weight did not significantly change during the observed period (Table 1), absolute PT (Nm), Pmax (W) and TPT (s) were used for the purposes of assessment of seasonal variation.

After three minutes of active rest, the players performed two jumping tests to measure the explosive strength of their lower extremities - countermovement jump with free arms (CMJF) and countermovement jump with arm crossed over the chest (CMJ). The higher value $(\mathrm{cm})$ of the two trials was used for the analysis; the rest interval was 30 seconds. A dynamometric platform (Kistler Instrumente, Winterthur, Switzerland) measuring the magnitude of the ground reaction force during the jump was used. Prior to testing, the players completed specific warm-up exercises which included ten jumps with a progressive increase in height.

\section{Terms of measurement}

The three repeated measurements were performed in the different phases of the training process - the first at the end of the competitive season, the second at the beginning of the off-season after a three-week holiday and the third during the sixth week of a new competitive season. Both tests were performed on one day; the isokinetic test was first followed by the jump test.

\section{Statistical analysis}

To assess the correlations between the isokinetic strength characteristics (PT, Pmax, TPT) and the height of vertical jumps (CMJF and CMJ) the Spearman's correlation coefficient was used. The value of the correlation coefficient was analysed as follows: $<.30$ low; .31-.69 moderate; .70-1.00 high (Morrow, Jackson, Disch, \& Mood, 2005). Based on literary reviews (Malliou et al., 2003; Özcakar et al., 2003; Ostenberg et al., 1998; Tsiokanos, Kellis, Jamurtas, \& Kellis, 2002; Blackburn \& Morrissey, 1998; Saliba \& Chrysomallis, 2001; Iossifidou, Baltzopoulos, \& Giakas, 2005), a logically significant value of the correlation coefficient was set at $>.30$. Statistical processing was performed by means of STATISTICA 10 (StatSoft, Inc., Tulsa, OK, USA).

\section{RESULTS}

The correlation between isokinetic variables and vertical jump performance irrespective of the ATC period

Means and standard deviations of observed variables are in Table 2. The correlation values between the characteristics of isokinetic strength of knee extensors and the height of applied types of vertical jumps irrespective of the monitored periods were low to moderate (Figure 1). Out of the total number of 36 possible correlations, a correlation value exceeding .30 was identified in 20 cases $(56 \%)$. In most parameters the correlations were higher for CMJ than CMJF. The highest correlations were identified at an angular velocity of $180^{\circ} \cdot \mathrm{s}^{-1}$. At all angular velocities the correlation for PT and Pmax is higher in the dominant leg compared with the non-dominant leg (except Pmax correlation at an angular speed of $60^{\circ} \cdot \mathrm{s}^{-1}$ and $\mathrm{CMJF}$ ).

\section{The correlation between isokinetic variables and vertical jump performance in the different ATC periods}

The number of correlations $>.30$ and the value of the correlations varied in the different ATC training periods. During the first measurement after the competi- 
Table 2

Isokinetic and explosive strength characteristics (mean $\pm S D$ )

\begin{tabular}{|c|c|c|c|c|c|c|}
\hline & \multicolumn{2}{|c|}{ Measurement 1} & \multicolumn{2}{|c|}{ Measurement 2} & \multicolumn{2}{|c|}{ Measurement 3} \\
\hline & $M_{\mathrm{DL}} \pm S D$ & $M_{\mathrm{NL}} \pm S D$ & $M_{\mathrm{DL}} \pm S D$ & $M_{\mathrm{NL}} \pm S D$ & $M_{\mathrm{DL}} \pm S D$ & $M_{\mathrm{NL}} \pm S D$ \\
\hline \multicolumn{7}{|c|}{ Peak torque $(\mathrm{Nm})$} \\
\hline $\mathrm{AV} 60^{\circ} \cdot \mathrm{s}^{-1}$ & $211 \pm 37$ & $195 \pm 38$ & $204 \pm 34$ & $191 \pm 29$ & $207 \pm 34$ & $195 \pm 31$ \\
\hline $\operatorname{AV} 180^{\circ} \cdot \mathrm{s}^{-1}$ & $151 \pm 23$ & $144 \pm 21$ & $153 \pm 20$ & $143 \pm 18$ & $157 \pm 18$ & $151 \pm 18$ \\
\hline $\operatorname{AV} 360^{\circ} \cdot \mathrm{s}^{-1}$ & $112 \pm 26$ & $105 \pm 31$ & $111 \pm 29$ & $117 \pm 17$ & $121 \pm 23$ & $112 \pm 27$ \\
\hline \multicolumn{7}{|l|}{ Peak power (W) } \\
\hline $\mathrm{AV} 60^{\circ} \cdot \mathrm{s}^{-1}$ & $141 \pm 27$ & $136 \pm 24$ & $142 \pm 26$ & $133 \pm 21$ & $147 \pm 22$ & $134 \pm 25$ \\
\hline $\operatorname{AV} 180^{\circ} \cdot \mathrm{s}^{-1}$ & $231 \pm 37$ & $226 \pm 43$ & $245 \pm 39$ & $227 \pm 39$ & $244 \pm 62$ & $234 \pm 53$ \\
\hline $\operatorname{AV} 360^{\circ} \cdot \mathrm{s}^{-1}$ & $228 \pm 64$ & $214 \pm 64$ & $233 \pm 75$ & $238 \pm 38$ & $239 \pm 82$ & $214 \pm 79$ \\
\hline \multicolumn{7}{|c|}{ Time to peak torque (s) } \\
\hline $\operatorname{AV} 60^{\circ} \cdot \mathrm{s}^{-1}$ & $370 \pm 75$ & $334 \pm 106$ & $342 \pm 77$ & $323 \pm 90$ & $305 \pm 67$ & $348 \pm 85$ \\
\hline AV $180^{\circ} \cdot \mathrm{s}^{-1}$ & $153 \pm 38$ & $133 \pm 39$ & $122 \pm 44$ & $118 \pm 50$ & $107 \pm 42$ & $109 \pm 42$ \\
\hline $\operatorname{AV} 360^{\circ} \cdot \mathrm{s}^{-1}$ & $193 \pm 56$ & $217 \pm 51$ & $212 \pm 85$ & $203 \pm 53$ & $185 \pm 80$ & $214 \pm 62$ \\
\hline CMJF (cm) & $45 \pm 5$ & & $40 \pm 3$ & & $43 \pm 3$ & \\
\hline $\mathrm{CMJ}(\mathrm{cm})$ & $38 \pm 4$ & & $37 \pm 3$ & & $39 \pm 4$ & \\
\hline
\end{tabular}

Note. $\quad M_{\mathrm{DL}}=$ mean of dominant leg, $M_{\mathrm{NL}}=$ mean of non-dominant leg.

AV $60^{\circ} \cdot \mathrm{s}^{-1}=$ angular velocity $60^{\circ} \cdot \mathrm{s}^{-1}$, AV $180^{\circ} \cdot \mathrm{s}^{-1}=$ angular velocity $180^{\circ} \cdot \mathrm{s}^{-1}$, AV $360^{\circ} \cdot \mathrm{s}^{-1}=$ angular velocity $360^{\circ} \cdot \mathrm{s}^{-1}$. $\mathrm{CMJF}=$ jump height during countermovement jump with free arms, $\mathrm{CMJ}=$ jump height during countermovement jump with the arms crossed over the chest.

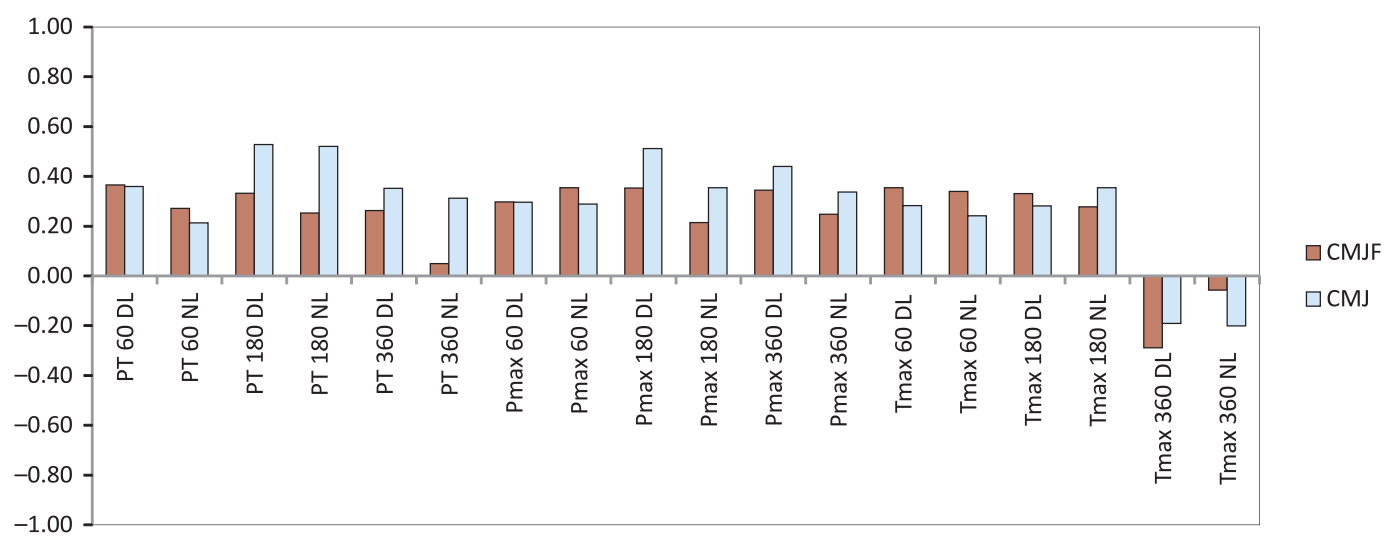

Figure 1. The correlation values between isokinetic variables in the dominant and non-dominant leg and the height of vertical jumps irrespective of the period of the ATC

tive season the correlation value was $>.30$ in 24 cases (67\%), during the second measurement after the period without training in 11 cases $(31 \%)$ and during the third measurement at the beginning of the competitive season in 23 cases (64\%), (Figure 2, 3). The correlation for Pmax and PT were the lowest during the second measurement in most cases. No meaningful trend was observed for TPT.

In the case of CMJF, the highest correlation values were observed for Pmax in the dominant leg at veloci- ties of $180^{\circ} \cdot \mathrm{s}^{-1}$ and $360^{\circ} \cdot \mathrm{s}^{-1}$ during the third measurement ( $r=.65$ and $r=.65$ ). In the case of CMJ the highest values were observed during the first measurement for both Pmax and PT at a speed of $180^{\circ} \cdot \mathrm{s}^{-1}$ in the dominant leg $(r=.76$ and $r=.56)$. For both types of jumps the number of correlations $>.30$ also differed in the monitored periods. 


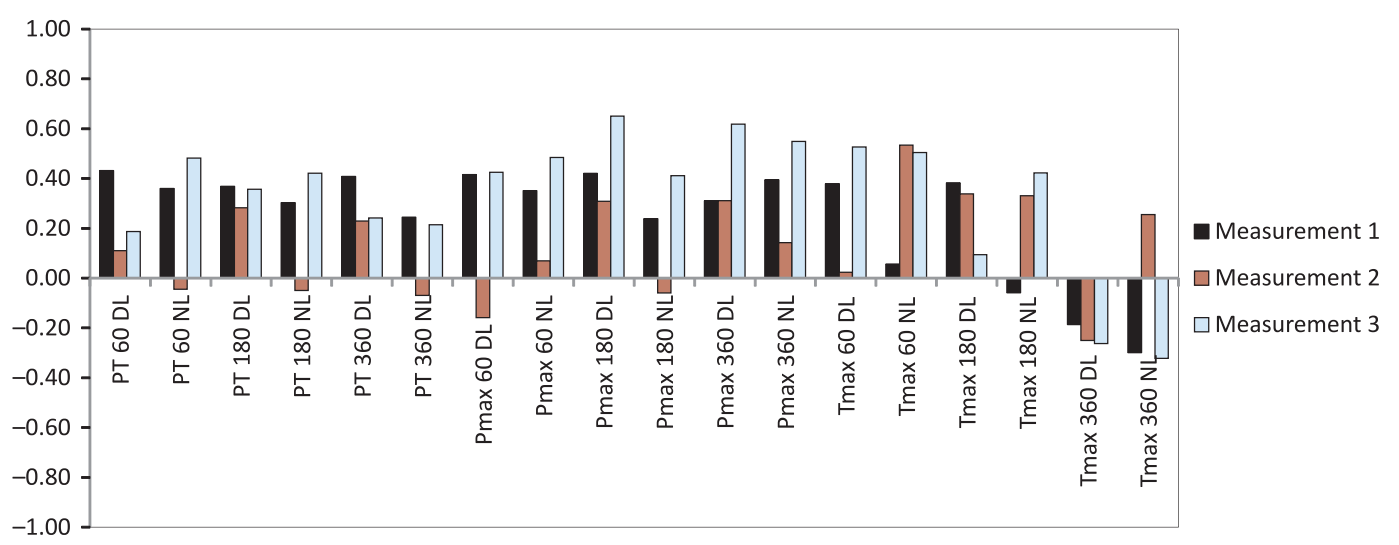

Figure 2. The correlation values between isokinetic variables in the dominant and non-dominant leg and the height of vertical jump with free arms in the monitored periods of the annual training cycle

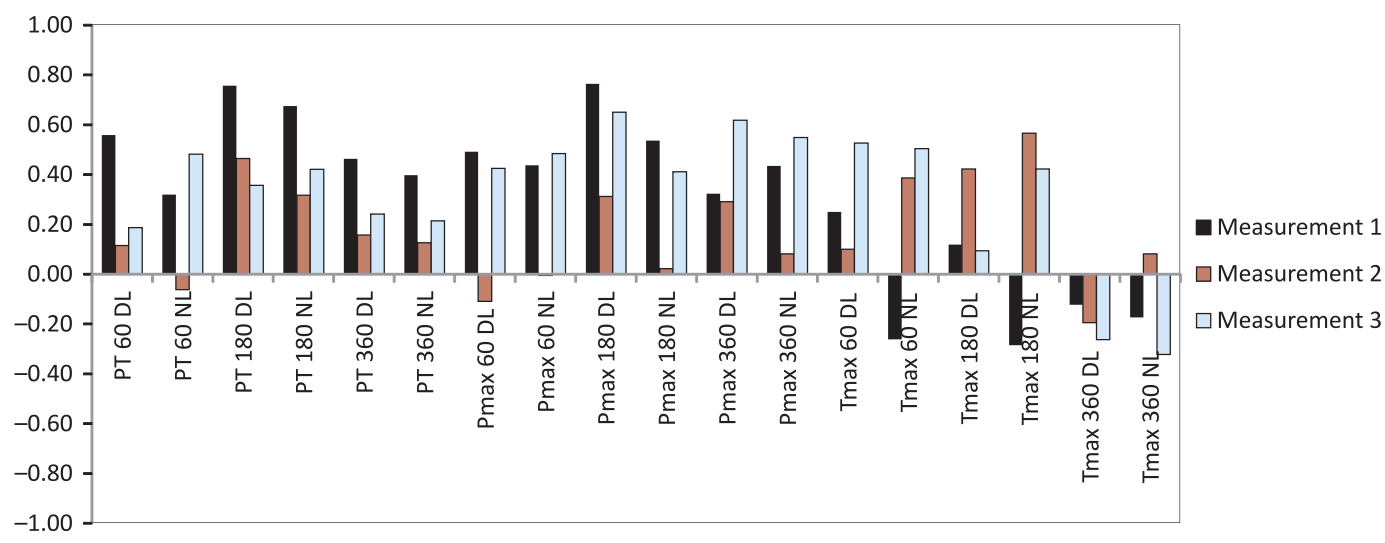

Figure 3. The correlation values between isokinetic variables in the dominant and non-dominant leg and the height of vertical jump with the arms crossed over the chest in the monitored periods of the annual training cycle

\section{DISCUSSION}

The correlation between isokinetic variables and vertical jump performance irrespective of the ATC period In our study we observed low to moderate correlations and, in two cases, high correlations between the characteristics of the isokinetic strength of knee extensors and the heights of the applied types of vertical jumps irrespective of the monitored period. Out of the total number of correlations, $56 \%$ of correlations exceeded .30. For interpretation of the results, the differences between both types of movement must be considered. Vertical jump is a multi-joint movement with a closed kinematic chain and, in terms of soccer, a movement with a high degree of specificity. On the contrary, extension of the knee joint is a single-joint movement with an open kinematic chain. In spite of the fact that the quadriceps thigh muscle is significantly employed during the take off stage of vertical jump (Rodacki, Fowler, \& Bennett, 2002; Whiting \& Rugg, 2006), the study confirmed that the measured results of the isokinetic strength of knee extensors provide only partial information in terms of the take off explosiveness of a player. However, ambiguous results were also presented in studies dealing with the correlation between the isokinetic strength of the knee extensors in a closed kinematic chain (leg press) and vertical jump performance. Blackburn and Morrisey (1998) observed moderate to high correlations between the mentioned parameters. On the other hand, Kovaleski et al. (2001) discovered only low correlations between PT of knee extensors measured at a velocity of $60^{\circ} \cdot \mathrm{s}^{-1}$ and also PT during leg press and a single-leg vertical jump performance.

In terms of angular velocities of isokinetic testing, in the case of CMJF we observed the highest correlation values for Pmax in the dominant leg at velocities of $180^{\circ} \cdot \mathrm{s}^{-1}$ and $360^{\circ} \cdot \mathrm{s}^{-1}$ (third measurement). In the case of $\mathrm{CMJ}$ the highest correlation values were observed for Pmax and PT at a velocity of $180^{\circ} \cdot \mathrm{s}^{-1}$ in the dominant leg (first measurement). The results indicate that a higher correlation can be expected for moderate to high angular velocities of the isokinetic movement. A similar trend was confirmed by the results of a study of U16 elite male players (Malý et al., 2013). The au- 
thors observed that the correlation between CMJF and isokinetic concentric PT of knee flexors and extensors at velocities of $60^{\circ} \cdot \mathrm{s}^{-1}, 120^{\circ} \cdot \mathrm{s}^{-1}, 180^{\circ} \cdot \mathrm{s}^{-1}, 240^{\circ} \cdot \mathrm{s}^{-1}$ and $360^{\circ} \cdot \mathrm{s}^{-1}$ were low to moderate and that their value increased with increasing angular velocity of the isokinetic movement. However, a significant correlation was recorded only in the case of PT of knee flexors at a velocity of $360^{\circ} \cdot \mathrm{s}^{-1}$. The speed of the movement is considered one of the key specificity features. Therefore we assume that the observed higher correlation values at higher speeds can be associated with increasing specificity of the isokinetic movement in the knee joint.

The results of the current study can also be compared with the results of a study by Tsiokanos, Kellis, Jamurtas et al. (2002). The authors verified the correlation between the vertical jump performance CMJ (hands fixed on the hips) and the squat jump and isokinetic concentric strength of the muscle groups of the lower extremities in a group of male students in physical education. The results indicated moderate correlations between the isokinetic strength and $\mathrm{CMJ}$ with the highest correlations observed at a speed of $180^{\circ} \cdot \mathrm{s}^{-1}$. However, when the CMJ height was substituted with the mechanical work performed during CMJ, high correlations between PT and $\mathrm{CMJ}$ were revealed at all measured velocities $\left(60^{\circ} \cdot \mathrm{s}^{-1}, 120^{\circ} \cdot \mathrm{s}^{-1}\right.$ and $\left.180^{\circ} \cdot \mathrm{s}^{-1}\right)$.

In the present study we also observed slightly higher correlations for PT and Pmax in the dominant leg compared with the non-dominant leg at all angular velocities except Pmax correlation at an angular speed of $60^{\circ} \cdot \mathrm{s}^{-1}$ and CMJF (Figure 2, 3). This result complies with the results of a study by Malý et al. (2013) performed in the U16 category. A similar trend was also observed by Malliou et al. (2003), but only after the competitive season. Regarding the minimum PT and Pmax differences between the dominant and non-dominant leg in our sample (not mentioned in this study) we assume that the primary cause could be better neuromuscular coordination in the dominant leg preferably used by players during workouts and matches to kick the ball.

\section{The correlation between isokinetic variables and vertical jump performance in the different ATC periods}

The aim of the study was to investigate the correlation between the characteristics of the isokinetic strength of knee extensors and vertical jump performance in three ATC periods. The results of the study indicate that the correlation between the characteristics of the isokinetic strength during knee flexion and extension and vertical jump performance in elite adolescent players during the monitored ATC periods varied and was also different for individual angular velocities. The number of correlations $>.30$ and the value of the correlations varied in the different ATC periods. The highest num- ber of correlations $>.30$ were observed at the end of the competitive season (first measurement) and at the beginning of a new competitive season, particularly at a velocity of $180^{\circ} \cdot \mathrm{s}^{-1}$ (Figure 2, 3).

We assume that the higher number and also the higher values of correlations in case of the first and the third measurement may possibly be attributed to the specific training load in the off-season and in the competitive season during which fast muscle actions appeared frequently in soccer specific exercises, game activities and fitness exercises. On the other hand, the decrease in the number of correlations and their values observed in the second measurement could be influenced by the loss of specific adaptations after the period without training(Bompa \& Carrera, 2004; Issurin, 2010). The players were not subject to individual training plans for this phase and this was a phase of active rest with minimum strength training. A lower level of neuromuscular control of movements during the transitional period as a result of non-specific training was observed by Inklaar (1994). According to the author, this is the cause of an increased number of injuries during this season.

The changes observed in our study during the monitored ATC periods are similar to the results of a study by Malliou et al. (2003). The authors determined the correlations between the isokinetic concentric strength of knee extensors (PT at a velocity of $60^{\circ} \cdot \mathrm{s}^{-1}$ and $180^{\circ} \cdot \mathrm{s}^{-1}$ ) and vertical jump performance in various ATC periods in professional soccer players. They observed a changing pattern of the correlations throughout the ATC. The correlations at the end of the preparatory period were moderate to high $(r=.43$ to $r=.78)$, at the end of the competitive season low to moderate ( $r=.39$ to $r=.69$ ) and at the end of the transitional period negligible $(r=.14$ to $r=.26)$. The authors attribute this fact to a weaker influence of neuromuscular factors as a result of a deficiency in specific football exercise during this period. In female players, Östenberg et al. (1998) did not observe statistically significant correlations between the isokinetic muscle strength of extensors and various types of vertical jumps at a velocity of $60^{\circ} \cdot \mathrm{s}^{-1}$, which corresponds to our findings only at the end of transitional period. Nevertheless, significant correlations were confirmed during all three periods at a velocity of $180^{\circ} \cdot \mathrm{s}^{-1}$, which indicates similar trends as in our study.

Apart from the trends mentioned above, the values of the correlations and the number of correlations $>.30$ for the applied types of jumps in the different ATC training periods also varied. In the case of CMJF the highest correlations were observed during the third measurement (at the beginning of a new competitive period) for Pmax in the dominant leg at velocities of $180^{\circ} \cdot \mathrm{s}^{-1}$ and $360^{\circ} \cdot \mathrm{s}^{-1}$. In the case of CMJ the highest 
correlation values were recorded during the first measurement (immediately after the competitive period) for Pmax and PT at a velocity of $180^{\circ} \cdot \mathrm{s}^{-1}$ in the dominant leg. The causes of this difference are unknown to the authors. The lowest correlations for both types of vertical jump were observed in the second measurement, i.e. after a three-week rest (Figure 2, 3).

\section{CONCLUSIONS}

The present study confirmed that the correlations between the characteristics of the isokinetic strength during knee extension and the height of applied types of vertical jumps (irrespective of the training period) is primarily low to moderate in adolescent soccer players. However, the observed difference in the correlations during the different ATC periods implies that the significance of the information obtained by measuring the strength of isokinetic extension of the knee joint to assess the jumping ability in soccer players can change during the ATC. The results also indicate that, from this perspective, measurement at $180^{\circ} \cdot \mathrm{s}^{-1}$ or at higher velocities should be preferred for knee extension.

\section{ACKNOWLEDGMENT}

This study was supported by a research grant of Palacký University, Olomouc FTK_2012_006 and was a part of a research project of the Faculty of Physical Culture (No. 6198959221) which was supported by the Ministry of Education, Youth and Sport of the Czech Republic.

\section{REFERENCES}

Anthrakidis, N., Skoufas, D., Lazaridis, S., \& Zaggelidis, G. (2008). Relationship between muscular strength and kicking performance. Physical Training, October. Retrieved from http://ejmas.com/ pt/2008pt/ptart_zaggelidis_0810.html

Baltzopoulos, V., \& Brodie, D. A. (1989). Isokinetic dynamometry: Applications and limitations. Sports Medicine, 8(2), 101-116.

Bompa, T., \& Carrera, M. (2005). Periodization training for sports. Champaign, IL: Human Kinetics.

Bradley, P. S., Sheldon, W., Wooster, B., Olsen, P., Boanas, P., \& Krustrup, P. (2009). High intensity running in English FA Premier League soccer matches. Journal of Sports Sciences, 27(2), 159-168.

Bračič, M., Hadžič, V., Čoh, M., \& Derviševič, E. (2011). Relationship between time to peak torque of hamstrings and sprint running performance. Isokinetics and Exercise Science, 19(4), 281-286.
Bravo, D. F., Impellizzery, F. M. Rampinini, E., Castagna, C., Bishop, D., \& Wisloff, U. (2008). Sprint vs. interval training in football. International journal of sports medicine, 29(8), 668-674.

Brown, L. E. (2000). Isokinetics in human performance. Champaign, IL: Human Kinetics.

Cerrah, A. O., Gungor, E. O., Soylu, A. R., Ertan, H., Lees, A., \& Bayrak, C. (2011). Muscular activation patterns during the soccer in-step kick. Isokinetics and Exercise Science, 19(3), 181-190.

Cometti, G., Maffiuletti, N. A., Pousson, M., Chatard, J. C., \& Maffuli, N. (2001). Isokinetic strength and anaerobic power of elite, subelite and amateur French soccer players. International Journal of Sports Medicine, 22, 45-51.

Cotte, T., \& Chatard, J. C. (2011). Isokinetic strength and sprint times in English premier league football players. Biology of Sport, 28(2), 89-94.

DeStaso, J., Kaminski, T. W., \& Perrin, D. H. (1997). Relationship between drop vertical jump heights and isokinetic measures utilizing the stretchshortening cycle. Isokinetic and Exercise Science, 6, 175-179.

Dirnberger, J., Kösters, A., \& Müller, E. (2012). Concentric and eccentric isokinetic knee extension: A reproducibility study using the IsoMed 2000-dynamometer. Isokinetics and Exercise Science, 20(1), 31-35.

Ekblom, B. (1994). Football. Blackwell: Scientific Publication.

Gamble, P. (2010). Strength and conditioning for team sports: Sport specific physical preparation for high performance. London: Taylor and Francis.

Hoff, J. (2004). Training and testing physical capacities for elite soccer players. Journal of Sport Sciences, 23(6), 573-582.

Hoff, J., \& Helgerud, J. (2004). Endurance and strength training for soccer players (physiological considerations). Sports Medicine, 34, 165-180.

Inklaar, H. (1994). Soccer injuries II: Aetiology and prevention. Sports Medicine, 18(2), 81-93.

Iossifidou, A., Baltzopoulos, V., \& Giakas, G. (2005). Isokinetic knee extension and vertical jumping: Are they related? Journal of Sports Sciences, 23(10), 1121-1127.

Issurin, V. B. (2010). New horizons for the metodology and physiology of training periodization. Sports Medicine, 40(3), 189-206.

Kannus, P. (1994). Isokinetic evaluation of muscular performance: Implications for muscle testing and rehabilitation. International Journal of Sports Medicine, 15(1), 11-18.

Kovaleski, J. E., Heitman, R. J., Andrew, D. P., Gurchiek, L. R., \& Pearsall, A. W. (2001). Relationship between closed-linear-kinetic- and open-kinetic-cha- 
in isokinetic strength and lower extremity functional performance. Journal of Sport Rehabilitation, 10(3), 196-204.

Lehance, C., Binet, J., Bury, T., \& Croisier, J. N. K. (2009). Muscular strength, functional performances and injury risk in professional and junior elite soccer players. Scandinavian Journal of Medicine \& Science in Sport, 19(2), 243-251.

Luhtanen, P., \& Komi, P. V. (1978). Segmental contribution to forces in vertical jump. European Journal of Applied Physiology, 38, 181-188.

Malliou, P., Ispirlidis, I., Beneka, A., Taxildaris, K., \& Godolias, G. (2003). Vertical jump and knee extensors isokinetic performance in professional soccer players related to the phase of the training period. Isokinetics and Exercise Science, 11(3), 165-169.

Malý, T., Zahálka, F., Malá, L., Hráský, P., Buzek, M., \& Gryc, T. (2011). Relationships between isokinetic knee strength, sprint and jump performance in young elite soccer players. Footbal Science, 8(Suppl. 1), 237.

Morrow, J. R., Jackson, A. W., Disch, J. G., \& Mood, D. P. (2005). Measurement and evaluation in human performance. Champaign, IL: Human Kinetics.

Newman, M. A. (2004). Relationship between isokinetic knee stregth, single-sprint performance, and repeated-sprint ability in football players. Journal of Strength and Conditioning Research, 18(4), 867-872.

Östenberg, A., Roos, E., Ekdahl, C., \& Roos, H. (1998). Isokinetic knee extensor strength and functional performance in healthy female soccer players. Scandinavian Journal of Medicine \& Science in Sport, 8(5), 257-264.

Özcakar, L., Kunduracyoğlu, B., Cetin, A., Ülkar, B., Guner, R., \& Hascelik, Z. (2003). Comprehensive isokinetic knee measurements and quadriceps tendon evaluations in footballers for assessing functional performance. Sports Medicine, 37(6), 507-510.

Saliba, L., \& Hrysomallis, C. (2001). Isokinetic strength related to jumping but not kicking performance of Australian footballers. Journal of Science and Medicine in Sport, 4(3), 336-347.

Rodacki, A. L. F., Fowler, N. E., \& Bennett, S. J. (2002). Vertical jump co-ordination: Fatigue effects. Medicine Science in Sports and Exercise, 34(1), 105-16.

Schmid, S., \& Alejo, B. (2002). Complete conditioning for soccer. Champaign, IL: Human Kinetics.

StatSoft, Inc. (2010). Statistica 10 [Computer Software]. Tulsa, OK: StatSoft.

Stølen, T., Chamari, K., Castagna, C., \& Wisloff, U. (2005). Physiology of soccer. Sports Medicine, 35(6), 501-536.
Stone, Me., \& Stone, Mi. (2006). Recovery - adaptation: Strength/power sports. Retrieved from http:// coachesinfo.com/category/strength_and_conditioning/270/

Tsiokanos, A., Kellis, E., Jamurtas, A., \& Kellis, S. (2002). The relationship between jumping perfomance and isokinetic strength of hip and knee extensors and ankle plantar flexors. Isokinetic and Exercise Science, 10(1), 107-115.

Verheijen, R. (1998). Conditioning for soccer. Spring City, PA: Reedswain.

Whiting, W. C., \& Rugg, S. (2006). Dynatomy: Dynamic human anatomy. Champaign, IL: Human Kinetics.

Wirth, K., \& Schmidtbleicher, D. (2007). Periodisierung im schnellkrafttraining. Leistungssport, 37(2), 16-20.

Wisloff, U., Castagna, C., Helgerud, J., Jones, R., \& Hoff, J. (2004). Strong correlation of maximal squat strength with sprint performance and vertical jump height in elite soccer players. British Journal of Sports Medicine, 38, 285-288.

Wrigley, T. W. (2000). Assessment for football: Soccer, Australian rules, and American. In L. E. Brown (Ed.), Isokinetics in human performance (pp. 407-428). Champaign, IL: Human Kinetics.

\section{KORELACE MEZI IZOKINETICKOU SILOU EXTENZORŮ KOLENA A VÝKONEM VE VER- TIKÁLNÍM SKOKU V PRŮBĚHU ROČNÍHO TRÉNINKOVÉHO CYKLU U ADOLESCENTNÍCH FOTBALISTŮ}

(Souhrn anglického textu)

ÚVOD: Izokinetické testování bývá často používáno s cílem poskytnout trenérům důležité informace o trénovanosti sportovců. Řada studií se proto zabývá hodnocením vztahu mezi izokinetickými a funkčními testy. Výsledky omezeného počtu prací ukazují, že tento vztah se v různých tréninkových obdobích mění.

CíL: Cílem studie bylo zjistit vztah mezi charakteristikami izokinetické síly extenzorů kolene a výškou vertikálního skoku ve třech různých obdobích ročního tréninkového cyklu u adolescentních fotbalistů.

METODIKA: Skupina adolescentních fotbalistů ( $N=16$; průměrný věk $16,7 \pm 0,7$ roků) byla testována na konci soutěžního období, na začátku přípravného období a v průběhu šestého týdne nového soutěžního období. Izokinetický maximální moment síly (PT), maximální výkon (Pmax) a čas potřebný pro dosažení PT (TPT) u dominantní a nedominantní dolní končetiny byly měřeny při úhlových rychlostech $60^{\circ} \cdot \mathrm{s}^{-1}, 180^{\circ} \cdot \mathrm{s}^{-1}$, $360^{\circ} \cdot \mathrm{s}^{-1}$. Výbušná síla dolních končetin byla hodnocena testy vertikální skok $\mathrm{z}$ místa $\mathrm{s}$ pažemi (CMJF) 
a vertikální skok z místa s pažemi zkř́iženými na prsou (CMJ). Na základě analýzy literárních poznatků byla logická významnost korelace stanovena na hodnotu $>0,30$.

VÝSLEDKY: Korelace mezi izokinetickými charakteristikami síly a výškou vertikálních skoků bez ohledu na tréninkové období byly nízké až střední; 56 \% korelací bylo $>0,30$. V odlišných obdobích ročního tréninkového cyklu byl výskyt korelací > 0,30, stejně jako jejich hodnot, odlišný - 67 \% na konci soutěžního období, $31 \%$ na začátku přípravného období, 64 \% na začátku soutěžního období. Korelace mezi oběma typy skoků a Pmax, resp. PT byly ve většině případů nejnižší během druhého měření. $V$ př́ípadě korelace mezi oběma typy skoků a TPT nebyl pozorován žádný trend. Mezi
CMJF a Pmax byly zjištěny nejvyšší hodnoty korelace $\mathrm{v}$ případě třetího měření u dominantní dolní končetiny v rychlosti $180^{\circ} \cdot \mathrm{s}^{-1}$ a $360^{\circ} \cdot \mathrm{s}^{-1}$; mezi CMJ a Pmax, resp. PT v př́ípadě prvního měření v rychlosti $180^{\circ} \cdot \mathrm{s}^{-1} \mathrm{u}$ dominantní dolní končetiny.

ZÁVĚRY: Výsledky studie naznačují, že význam informací získaných izokinetickým měřením síly při extenzi kolenního kloubu pro posouzení odrazových predpokladů adolescentních fotbalistů se může $\mathrm{v}$ průběhu ročního tréninkového cyklu měnit a že z tohoto pohledu by mělo být upřednostňováno měření při rychlosti $180^{\circ} \cdot \mathrm{s}^{-1}$ a při rychlostech vyšších.

Klíčová slova: periodizace, sportovní trénink, testování, mládež. 